\title{
PEMENUHAN HAK MASYARAKAT HUKUM ADAT \\ DALAM PENGUASAAN HUTAN ADAT \\ DI KABUPATEN LAMPUNG BARAT
}

\author{
Hadri \\ Fakultas Hukum Universitas Muhammadiyah Metro \\ Email : hadrilawfirm@gmail.com
}

\begin{abstract}
Forests are very complex natural ecosystems containing various species of plants ranging from small to large-sized plants. Indigenous peoples are cultural entities that inhabit certain areas. The lives of indigenous people are subject to the customary norms that they agree to as the norm of mutual agreement to regulate the patterns of life of indigenous groups. The birth of law no. 41 of 1999 concerning forestry has changed the status of customary forests not State forests. The law by the alliance of indigenous peoples (safe) was conducted judicial review and through the constitutional court decision No: 35 / PUU-X / 2012, returning the legal status of customary land from state land to customary land. The study was conducted in a normative juridical manner in the West Lampung regency indigenous peoples to find out the implementation of the rights of indigenous peoples in the management and use of customary lands in West Lampung Regency after the decision of the Constitutional Court Number: 35 / PUU-X / 2012. From the results of the study, it was said that the management and utilization of the customary forests in the West Lampung Regency area had been made and implemented in the
\end{abstract}


West Lampung District Regulation No. 18 of 2004 concerning the management of natural resources and community-based environment, so that the customary law community in West Lampung can manage customary forests as a source of livelihood for people who live as mayors.

Keyword : Customary Law Society, Customary Forest, Customary Rights

\section{Abstrak}

Hutan merupakan ekosistem alamiah yang sangat kompleks mengandung berbagai spesies tumbuhan mulai dari tumbuhan kecil hingga berukuran besar. Masyarakat adat merupakan entitas kebudayaan yang mendiami wilayah tertentu. Kehidupan masyarakat adat tunduk pada norma-norma adat yang mereka sepakati sebagai norma kesepakatan bersama untuk mengatur pola kehidupan kelompok masyarakat adat. Lahirnya undangundang no. 41 tahun 1999 tentang kehutanan telah mengubah status hutan adat bukan hutan Negara. Undang-undang tersebut oleh aliansi masyarakat adat nusantara (aman) dilakukan uji materil (judicial review) dan melalui keputusan mahkamah konstitusi No:35/PUU-X/2012, mengembalikan status hukum tanah adat dari tanah negara menjadi tanah adat. Penelitian dilakukan secara yuridis normatif pada masyarakat adat Kabupaten Lampung Barat guna mengetahui Implementasi hakhak masyarakat adat dalam pengelolaan dan pemanfaatan tanah adat di Kabupaten Lampung Barat pasca putusan Mahkamah Konstitusi Nomor : 35/PUU-X/2012. Dari hasil penelitian 
dikeathui bahwa pengelolaan dan pemanfaatan hutan adat yang ada di wilayah Kabupaten Lampung Barat, telah dibuat dan diberlakukan Peraturan Daerah Kabupaten Lampung Barat No. 18 tahun 2004 tentang pengelolaan sumber daya alam dan lingkungan berbasis masyarakat, sehingga masyarakat hukum adat di lampung barat dapat mengelola hutan adat sebagai sumber penghidupan masyarakat yang mayoritanyas hidup sebagai petani.

Kata Kunci : Masyarakat Hukum Adat,Hutan Adat, Hak Ulayat.

\section{Pendahuluan.}

Istilah masyarakat adat diambil dari terjemahan Bahasa Belanda yakni Indigenous Peoples, sedangkan istilah masyarakat hukum adat adalah merupakan terjemahan istilah Rechtgemenschap. Penggunaan istilah masyarakat adat makna nya lebih luas jika dibandingkan dengan istilah masyarakat hukum adat, karena masyarakat adat tidak hanya terbatas pada sekedar aspek hukum melainkan sangat erat kaitanya dengan dimensi cultural, religi dan sebagainya. Banyak Ahli yang menyatakan istilah masyarakat hukum adat hanya akan mempersempit entitas-entitas masyarakat adat sebatas entitas hukum akan tetapi secara yuridis justru istilah masyarakat hukum adat merupakan istilah yang tepat dalam kaitannya terhadap kajian ilmu hukum.

Kelaziman istilah yang digunakan dalam ilmu pengetahuan hukum adalah masyarakat hukum adat karena memiliki ciri-ciri komprehensif, hal ini didasarkan bahwa hak 
masyarakat adat hanya akan ada di masyarakat hukum adat oleh karena itu aspek hukum adatlah yang menjadi penentu. Kedua istilah masyarakat adat dan masyarakat hukum adat memiliki sejarah pemaknaan yang berbeda, dimana masyarakat hukum adat dilahirkan dan dirawat oleh pakar hukum adat yang lebih banyak di fungsikan untuk keperluan teoritis akademis yang membedakan identitas pada golongan pribumi yang memiliki system dan tradisi hukum sendiri dengan golongan eropah dan timur jauh yang memiliki system dan tradisi hukum secara tertulis ${ }^{1}$.

Beberapa pendapat Ahli memberikan pengertian mengenai istilah masyarakat hukum adat diantaranya Djamanat Samosir dalam buku yang berjudul Hukum Adat Indonesia menyebutkan bahwa "Masyarakat Hukum Adat" juga disebut juga dengan istilah "Masyarakat Tradisional atau Indigenous People yang sehari-harinya secara populer disebut dengan istilah masyarakat adat".

Istilah masyarakat adat mulai mendunia setelah pada tahun 1950an Badan Perserikatan Bangsa Bangsa (PBB) mempopulerkan isu tentang Indegenous Peoples atau masyarakat adat, dimana isu masyarakat adat tersebut berawal dari berbagai gerakan protes masyarakat asli (Native Peoples) di Amerika Utara yang meminta keadilan pembangunan setelah kehadiran sejumlah perusahaan trans nasional yang mereka kelola serta

${ }^{1}$ Husen Alting. 2010. Dinamika Hukum Dalam Pengakuan Dan Perlindungan Hak Masyarakat Hukum Adat Atas Tanah (Masa Lalu, Kini Dan Masa Akan Datang). LaksBang PRESSindo. Yogyakarta. Hal. 80. 
pengembangan sejumlah wilayah konserpasi oleh Pemerintah Amerika dan Kanada².

Dalam Kongres Masyarakat Adat Nusantara Pertama (KMAN 1) tanggal 17 Maret 1999 di hotel Indonesia Jakarta, yang dihadiri oleh lebih dari 400 pimpinan adat nusantara menyepakati istilah "Masyarakat Adat adalah kelompok masyarakat yang memiliki asal usul leluhur atau turun temurun yang mendiami wilayah geografis tertentu serta memiliki system nilai, ideologi, ekonomi, politik, budaya, social dan wilayah sendiri3"

Berdasarkan pendapat tersebut di atas, Penulis dalam tulisan ini mengikuti pendapat hasil Kongres Masyarakat Adat Nusantara dengan menggunakan istilah Masyarakat Adat, dikarenakan istilah tersebut lebih luas menyangkut identitas nilainilai kelompok masyarakat bukan hanya terbatas pada tatanan hukum belaka dan Penulis dalam penelitian mengambil obyek sample pada masyarakat adat dengan system hukum adat yang ada di Kabupaten Lampung Barat.

Kabupaten Lampung Barat adalah salah satu Kabupaten di Provinsi Lampung Indonesia yang dibentuk beradasarkan Undang-undang No. 6 Tahun 1991 Tanggal 16 Agustus 1991 yang merupakan pemerkaran dari Kabupaten Lampung Utara yang ibukotanya terletak di Liwa.

Luas wilayah Kabupaten Lampung Barat lebih kurang 3.368, $14 \mathrm{KM} \cap 2$ setelah pemekaran Kabupaten Pesisir barat atau

\footnotetext{
${ }^{2}$ Besse Sugiswati. Perlindungan Hukum Terhadap Eksistensi
} Masyarakat Adat Di Indonesia. Jurnal Perspektif . Volume XVII No. 1 Tahun 2012 Edisi Januari. Fakultas Hukum Universitas Wijaya Kesuma Surabaya. Hal. 32.

${ }^{3}$ Abrar Saleng. 2004. Hukum Pertambangan. UII Press Andico Multiplay. Yogyakarta. Hal. 4. 
seluas 10. 6\% dari luas wilayah Provinsi Lampung dengan batas wilayah sebelah Utara: Kabupaten Ogan Komering Ulu Selatan (Provinsi Sumatera Selatan). Sebelah Selatan Kabupaten Pesisir Barat dan Kabupaten Tanggamus.Sebelah Barat Kab. Pesisir Barat.Sebelah Timur Kabupaten Lampung Utara Kabupaten Way Kanan dan Kabupaten Tanggamus.

Daerah Kabupaten Lampung Barat didominsi tanah perbukitan pegunungan yang merupakan punggung bukit barisan, masyarakat yang mendiami wilayah Kabupaten Lampung Barat terdiri dari masyarakat pribumi asli suku lampung dan masyarakat pendatang (trans local) dari berbagai masyarakat suku luar seperti, Palembang, Padang, Jawa, Batak, dan sebagainya, yang kehidupannya Bertani mengelola dan memanfaatkan lahan hutan.

Luas kawasan hutan di Indonesia saat ini diperkirakan sekitar 124.023.000 hektar. ${ }^{4}$ Terbagi atas hutan lindung sekitar 29.917.000 hektar, suaka alam dan pelestarian alam sekitar 27.399.000 hektar, hutan produksi terbatas sekitar 27.687.000 hektar, hutan produksi tetap sekitar 28.897.000 hektar, hutan produksi yang dapat dikonversikan sekitar 15. 525 hektar. $^{5}$

Berdasarkan data yang diperoleh dari Kementerian Kehutanan dan Badan Pusat Statistik (BPS), desa yang berinteraksi dengan hutan di Indonesia ada sekitar 31.957 dan 71,06 \% dari desa-desa tersebut menggantungkan hidupnya dari sumber daya

${ }^{4}$ BPS, Luas Kawasan Hutan dan Perairan ${ }^{1}$ Menurut Provinsi (ribu ha), https://www.bps.go.id/linkTabelStatis/view/id/1716, diakses pada 16-05-2016 pukul 14.15 Wib.

${ }^{5}$ Ibid 
hutan. ${ }^{6}$ Hal ini menunjukkan bahwa kawasan hutan di Indonesia menjadi sumber penghidupan bagi masyarakat pedesaan. Hutan menjadi soko guru mata pencaharian masyarakat pedesaan untuk memenuhi kebutuhan hidup. Masyarakat hukum adat secara legal formil diakui keberabadaanya melalui Undang-Undang Dasar 1945 sebagaimana tersebut dalam pasal 18B (2) menyebutkan “Negara mengakui dan menghormati kesatuan-kesatuan masyarakat hukum adat serta hak-hak tradisionalnya sepanjang masih hidup dan sesuai dengan perkembangan masyarakat dan prinsip Negara Kesatuan Republik Indonesiayang diatur dalam undang-undang". ${ }^{7 B e r k a i t a n}$ dengan hak adat atas tanah adalah merupakan hak yang diatur dan dilindungi oleh Undang-Undang sebagaimana tersebut dalam Undang-Undang No. 5 tahun 1960 tentang undang-undang pokok agraria Pasal 2 menyebutkan "bahwa pelaksanaan hak menguasai dari negara dalam pelaksanaannya bisa dikuasakan kepada daerah-daerah swatantra dan masyarakat hukum adat sekedar diperlukan dan tidak bertentangan dengan kepentingan nasional menurut ketentuan peraturan pemerintah" demikian juga disebutkan didalam pasal 3 UUPA. “Bahwa pelaksanaan hak ulayat dan hak-hak yang serupa itu dari masyarakat hukum adat, sepanjang menurut kenyataan masih ada dan sesuai dengan kepentingan nasional dan negara dan tidak bertentangan dengan undang-undang dan peraturan yang lebih tinggi".Dengan adanya legitimasi aturan yang mengatur dan melindungi tentang hak masyarakat hukum adat

\footnotetext{
${ }^{6}$ Putusan Mahkamah Konstitusi Nomor : 35/PUU-X/2012

${ }^{7}$ Pasal 18B Ayat (2) UUD 1945. PASAL ini menjadi Dasar Melegitimasi Atas Keberadaan Masyarakat Adat Di Indonesia.
} 
atas pengelolaan tanah atau hutan, maka masyarakat hukum adat terlibat secara langsung dalam hal mengelola, memanfaatkan dan menjaga serta pelestarian hutan berikut ekosistemnya.

Dengan lahirnya Undang-Undang No. 41 tahun 1999 tentang kehutanan, dimana didalam pasal 1 sub f menyebutkan “Hutan Adat Adalah Hutan Negara Yang Berada Dalam Wilayah Masyarakat Hukum Adat".Dengan lahirnya undang-undang kehutanan tersebut telah memicu terjadinya konflik kepentingan dalam penguasaan tanah atau hutan antara pemerintah dengan masyarakat adat khususnya mengenai tanah adat atau tanah ulayat yang sebelumnya dikelola, dimanfaatkan serta dinikmati hasilnya oleh masyarakat adat secara turun temurun.

Akibat dari perubahan aturan mengenai pengelolaan hutan adat berdasarkan ketentunan undang-undang kehutanan dimaksud banyak masyarakat ter-kriminalisasi dihukum pidana penjara karena telah dianggap terbukti melakukan tindak pidana kehutanan, seperti contohnya beberapa konflik perselisihan antara masyarakat adat dengan pihak perhutani yang telah menimbulkan korban yakni BAKHTIAR yang merupakan warga masyarakat adat Turungan di desa Turungan Baji Sinjai Barat yang telah dijadikan Terdakwa dengan tuduhan merusak hutan yang di klaim Dinas Kehutanan Kabupaten Sinjai sebagai hutan produksi terbatas di tahun 2014, Majelis Hakim Pengadilan Negeri Sinjai Sulawesi Selatan dalam amar putusannya telah menyatakan BAHTIAR terbukti bersalah dengan menjatuhkan hukuman penjara selama 1 (Satu) tahun 1 (Satu) bulan dan denda sebesar Rp. 500.000.000,- (Lima ratus juta rupiah) subsidair 3 (Tiga) bulan penjara. Dalam pemeriksaan persidangan BAHTIAR merasa tidak 
bersalah dan tidak mengetahui jika tanah kebunnya tersebut telah menjadi hutan kawasan produksi sebagaimana yang telah di klaim oleh Dinas Kehutanan Kabupaten Sinjai Sulawesi Selatan, karena lokasi tanah tersebut merupakan kebun milik sendiri yang masuk dalam hutan adat Bonto Baru wilayah masyarakat adat Turungan yang dikelola secara turun temurun sejak nenek moyang. Kasus serupa sudah banyak terjadi di daerah-daerah termasuk juga terjadi dalam wilayah masyarakat adat Kabupaten Lampung Barat.

Dengan banyaknya terjadi korban kasus seperti halnya yang dialami oleh BAHTIAR tersebut maka Aliansi Masyarakat Adat Nusantara (AMAN) mengajukan gugatan uji materil (Judicial review) terhadap undang-undang No. 41 tahun 1999 tentang kehutanan ke Mahkamah Konstitusi, dan atas uji materil terhadap undang-undang kehutanan tersebut maka Mahkamah Konstitusi dalam putusannya No. 35/PUU-X/2012, Kamis Tanggal 16 Mei 2013 telah mengabulkan sebagian dari gugatan uji materil tersebut khusunya mengenai ketentuan pasal 1 sub f yang semula berbunyi "Hutan Adat Adalah Hutan Negara Yang Berada Dalam Wilayah Masyarakat Hukum Adat" menjadi "Hutan Adat Bukan Merupakan Hutan Negara".

Implementasi pasca putusan MK No. 35/PUU-X/2012 terhadap undang-undang 41 tahun 1999 tentang kehutanan tersebut, Pemerintah dalam penerapan hukumnya masih sangat jauh dari apa yang diharapkan oleh masyarakat adat nusantara, Pemerintah masih memandang kawasan hutan steril, dan masyarakat tidak boleh berada dalam hal pengelolaan, menikmati hasil hutan adat tersebut termasuk dalam pengelolaan serta 
pemanfaatan tanah atau hutan adat pada masyarakat hukum adat di Kabupaten Lampung Barat. Dengan latar belakang tersebut di atas, timbul permasalahan yakni : Bagaimana pemenuhan hak masyarakat adat dalam penguasaan hutan adat di Kabupaten Lampung Barat.

\section{Pembahasan.}

\section{Masyarakat Adat Di Indonesia}

Masyarakat adat berdasarkan pengertianKongres Masyarakat Adat Nusantara Pertama (KMAN 1) tanggal 17 Maret 1999 di hotel Indonesia Jakarta, yang dihadiri oleh lebih dari 400 pimpinan adat nusantara menyepakati istilah "Masyarakat Adat adalah kelompok masyarakat yang memiliki asal usul leluhur atau turun temurun yang mendiami wilayah geografis tertentu serta memiliki system nilai, ideologi, ekonomi, politik, budaya, social dan wilayah sendiri" merupakan entitas kebudayaan yang mendiami wilayah tertentu. Umumnya masyarakat adat hidup dalam satu wilayah secara turun temurun. Kehidupan masyarakat hukum adat tunduk pada norma-norma adat yang mereka sepakati sebagai norma kesepakatan bersama untuk mengatur pola kehidupan kelompok masyarakat adat.

Istilah masyarakat adat diatur didalam dasar konstitusi Negara Republik Indonesia Undang-Undang Dasar 1945 dimana konstitusi memuat hukum dasar penyelenggaraan negara Indonesia yang merupakan payung bagi lahirnya peraturan perundang-undangan di bawahnya. Pengakuan terhadap masyarakat hukum adat dalam ketentuan pasal 18B (2) 
ISTIחBATH : JURחAI HUKUm. VOI. I 5 nO.2. nOV. 2018

menyebutkan bahwa "Negara Mengakui dan meghormati kesatuan-kesatuan masyarakat hukum adat serta hak-hak tradisionalnya sepanjang masih hidup dan sesuai dengan perkembangan masyarakat dan prinsip Negara Kesatuan Republik Indonesia yang diatur didalam undang-undang".Lebih lanjut diterangkan dalam pasal 281 (3) menyebutkan bahwa "Identitas budaya dan hak masyarakat tradisional dihormati selaras dengan perkembangan zaman dan peradaban"

Terkait dengan masyarakat adat di daerah- daerah dalam wilayah NKRI masih terdapat kelompok masyarakat adat yang hidup dengan aturan-aturan lokak yang disepakati oleh kelompok masyarakat adat tersebut, baik masyarakat adat dengan tradisi hukum adat di Pulau Jawa maupun masyarakat hukum dengan tradisi hukum adat yang ada diluar Pulau Jawa.

Hak masyarakat adat dalam kaitannya dengan penguasaan hak atas tanah adat dijamin dan diatur oleh undang-undang sebagaimana disebutkan didalam pasal 2 dan pasal 3 UndangUndang No. 5 tahun 1960 tentang Undang-Undang Pokok Agraria yang menyebutkan bahwa "Pelaksanaan hak menguasai tanah dari negara dalam pelaksanaanya bisa dikuasakan kepada daerahdaerah swatantra dan masyarakat hukum adat". Serta diatur dalam Undang-Undang No. 6 Tahun 2015 Tentang Desa, Sedangkan terhadap hak-hak ulayat dan hak-hak yang serupa dari masyarakat hukum adat sepanjang menurut kenyataan masih ada dan sesuai dengan kepentingan nasional dilaksanakan oleh masyarakat adat setempat.

Masyarakat Adat Di Lampung Barat.

Kabupaten Lampung Barat adalah salah satu kabupaten di 
provinsi Lampung, Indonesia. Ibu kota kabupaten ini terletak di Liwa. Kabupaten ini dibentuk berdasarkan Undang-Undang Nomor 6 Tahun 1991 tanggal 16 Agustus 1991yang merupakan hasil pemekaran dari Kabupaten Lampung Utara. Kabupaten ini dominan dengan perbukitan dengan pantai di sepanjang pesisir barat Lampung. Daerah pegunungan yang merupakan punggung Bukit Barisan, ditempati oleh vulkanik quarter dari beberapa formasi. Daerah ini berada pada ketinggian 50 - > 1000 mdpl. Daerah ini dilalui oleh sesar Semangka, dengan lebar zona sebesar $\pm 20 \mathrm{Km}$. Pada beberapa tempat dijumpai beberapa aktivitas vulkanik dan pemunculan panas bumi. Dengan luas wilayah lebih kurang $2.064 \mathrm{~km}^{2}(61.5 \%$ merupakan kawasan hutan, terdiri dari 39.231,27 hektar Hutan Lindung dan 87.725 hektar TNBBS). Wilyah lampung barat secara administratif meliputi 15 Kecamatan, 131 Pekon (Desa) dan 5 Kelurahan

Wilayah Kabupaten Lampung Barat berbatasan dengan:

a. Sebelah Utara: Kab. Ogan Komering Ulu Selatan (Provinsi Sumatera Selatan);

b. Sebelah Selatan: Kab. Pesisir Barat dan Kab. Tanggamus;

c. Sebelah Barat: Kab. Pesisir Barat;

d. Sebelah Timur: Kab. Lampung Utara, Kab. Way Kanan, dan Kab. Tanggamus.

Lampung Barat dikenal dengan sebutan Tanah Saibetik atau Tanah Yang Indah dengan tatanan kehidupan masyarakat adat dengan system Patrilineal atau mengikuti garis kekerabatan dari keturunan ayah/bapak dimana harta pusaka, gelar dan nama suku diturunkan menurut garis ayah/bapak. Masyarakat adat 
Lampung Barat tergabung dalam 6 (Enam) kebuayan yakni :

1. Buay Belunguh yang berpusat di Pekon Kenali.

2. Buay Pernong yang berpusat di Pekon Batu Bekhak.

3. Buay Bejalan Diway yang berpusat di Pekon Negeri Ratu Kembahang.

4. Buay Nyerupa yang berpusat di Pekon Sukau.

5. Buay Bulan/Nerima berpusat di Cenggiring.

6. Buay Menyata/Anak Metuha berpusat di Pekon Luas.

Dari 6 (Enam) kebuayan tersebut di atas hanya 4 (Empat) yang menjadi raja (Paksi Pak) yang secara Bersama-sama memerintah Kerajaan Sekala Bekhak sedangkan 2 (Dua) kebuayan yang tidak memerintah yaitu Buay Menyata/Anak Metuha merupakan penghuni terdahulu sebelum masuknya agama islam yang banyak mendapat pengaruh dari kerajaan Minangkabau Sumatera Barat, sedangkan Buay Nerima adalah Nabbai/Mirul atau anak perempuan yang menikah di luar kebuayan ${ }^{8}$. Dengan demikian maka masyarakat hukum adat Kabupaten Lampung Barat pasca Pemerintahan Islam terbagi menjadi 4 (Empat) kepaksian atau yang disebut dengan Paksi Pak yang terdiri dari :

1. Kepaksian Buay Belunguh yang berpusat di Pekon Kenali.

2. Kepaksian Buay Pernong yang berpusat di Pekon Batu Bekhak.

3. Kepaksian Buay Bejalan Diway yang berpusat di Pekon Negeri Ratu Kembahang.

4. Kepaksian Buay Nyerupa yang berpusat di Pekon 


\section{ISTINBATH : JURAAL HUKUM. VOI. I 5 nO.2. nOV. 2018}

Sukau.

Sedangkan masyarakat adat di wialyah Pesisir Kabupaten Lampung Barat yang sebelumnya adalah wilayah Kabupaten Lampung Barat terdapat 16 (Enam belas) masyarakat hukum adat yang disebut dengan Marga. Wilayah pemerintahan adat margamarga di Pesisir Barat memiliki batas yang cukup jelas antara satu marga dengan marga lainnya dan dipimpin oleh seorang Saibatin atau Kepala Marga.

Masyarakat adat Lampung Barat, memiliki hutan adat yang sering disebut dengan hutan marga atau ulayat sebagai tempat sumber mata pencaharian masyarakat yang mayoritas sebagai petani. Dalam pengelolaan hutan adat tersebut sebelum lahirnya Undang-Undang Pokok Agraria No. 5 tahun 1960 pengelolaannya diatur oleh Pesirah Marga yang sekaligus adalah merupakan Tokoh Adat setempat.

Hutan adat tersebut pengelolaannya diserahkan kepada Kepala Suku Adat masing-masing kampung, seperti hal contohnya pengelolaan hutan adat di Kepaksian Buay Belunguh oleh Pasirah Kenali yang juga adalah merupakan Kepala Adat Tertinggi Kepaksian Buay Belunguh menentukan pembagian tanah adat tersebut ke masing-masing Kepala Suku Adat Kampung, misalnya tanah marga / ulayat yang sekarang menjadi wilayah Kecamatan Sekincau serta Kecamatan Batu Ketulis dahulunya adalah merupakan tanah adat perladangan Kampung Batin Kenali, Kampung Bumi Agung (Luppak Way), Kampung Bakhu, Kampung Kejadian, Kampung Sukarami, Kampung Bedudu, akan tetapi saat sekarang tanah-tanah adat atau tanah marga tersebut sudah banyak didiami oleh masyarakat pendatang. 
Sementara hutan adat yang berada di lereng bukit gunung Pesagi dikelola oleh masyarakat adat mulai dari Pematang Pekon Hujung, Pematang Pekon Luas, Pematang Pekon Serungkuk, Pematang Pekon Bumi Agung (Luppak Way), Pematang Pekon Turgak, Pematang Pekon Sukaraja (Kecamatan Batu Brak), Pematang Pekon Jajawi (Kecamatan Balik Bukit), Pematang Pekon Bukit Sawa (Kecamatan Pagar Dewa Dan Kecamatan Sukau) dikelola oleh Pemangku Adat Pekon masing-masing tersebut.

Dalam penelitian lapangan Penulis mengambil sample tanah adat Kepaksian Buay Benlunguh yang berada di lereng bukit gunung Pesagi yakni hutan adat Pekon Hujung, Pekon Luas, Pekon Serungkuk, Pekon Bumi Agung (Luppak Way), Pekon Turgak Kecamatan Belalau dan Pekon Sukaraja Kecamatan Batu Brak Kabupaten Lampung Barat. Diambilnya sample hutan adat pekon-pekon tersebut dikecamatan Belalau dan Kecamatan Batu Brak dikarenakan hutan adat tersebut keberadaannya masih diakui serta mayoritas masih dikelola dan merupakan sumber penghidupan masyarakat setempat baik untuk hunian tempat tinggal berupa kampung maupun sawah dan perladangan serta masih ada sebagian tanah adat tersebut yang diperuntukkan bagi masyarakat lokaluntuk mengambil kayu sebagai bahan untuk pembuatan rumah, sedangkan yang lainnya pengelolaannya diperuntukkan untuk tanah persawahan dan tanah perladangan kebun kopi dan tanaman keras lainnya.

Masyarakat adat setempat masih berpegang teguh pada tradisi bertanitradisional secara turun temurun dari nenek moyangnya terdahulu, demikian juga dengan pelestarian ekosistemnya masyarakat adat masih mematuhi petata petiti atau 
aturan yang diwarisi dari nenek moyangnya seperti pamali apabila menjual tanah dan sebagainya.

Akan tetapi masyarakat adat yang masih berpegang teguh dengan aturan adat tradisional dalam hal pengelolaan dan pemanfaatan hutan adat terusik dengan lahirnya Undang-Undang No. 41 tahun 1999 tentang kehutanan dimana pasal 1 sub f yang berbunyi “Hutan Adat Adalah Hutan Negara Yang Berada Dalam Wilayah Masyarakat Hukum Adat". Dengan undang-undang kehutanan tersebut Pemerintah melalui Dinas Kehutanan melakukan pelarangan-pelarangan pada sebagian tanah adat masing-masing kampung tersebut dan dijadikan menjadi hutanhutan negara dibawah kekuasaan Dinas Kehutanan Provinsi Lampung, sehingga dengan adanya ketentuan tersebut menimbulkan konflik kepentingan antara masyarakat adat dengan pemerintah yang mengakibatkan adanya masyarakat yang terkriminalisasi dengan tuduhan penyerobotan atau pengerusakan tanah negara, salah satu contoh kasus adalah masyarakat adat Pekon Serungkuk Kecamatan Belalau Kabupaten Lampung Barat yang dijatuhi pidana penjara dan denda, dinyatakan terbukti bersalah melakukan pengerusakan, perambahan hutan di Pematang Pekon Serungkuk Kecamatan Belalau Kabupaten Lampung Barat oleh Pengadilan Negeri Liwa. Regulasi Dan Peran Pemerintah Lampung Barat Dalam Melindungi Hak-Hak Masyarakat Hukum Adat.

Dalam konstitusi Negara Republik Indonesia Pasal 18B (2) Undang-Undang Dasar Negara Republik Indonesia Tahun 1945 menyatakan bahwa : "Negara mengakui dan menghormati 
ISTIחBATH : JURחAI HUKUm. VOI. I 5 nO.2. nOV. 2018

kesatuan-kesatuan masyarakat hukum adat beserta hak-hak tradisionalnya sepanjang masih hidup dan sesuai dengan perkembangan masyarakat dan prinsip Negara Kesatuan Republik Indonesia, yang diatur dalam undang-undang."

Sebagai implementasi konstitusi tersebut masyarakat adat nusantara yang diperkirakan beranggotakan 2.304 komunitas adat dengan visi untuk mewujudkan kehidupan yang adil dan sejahtera bagi semua masyarakat adat di Indonesia telah membentuk organisasi kemasyarakatan indevenden yang diberi nama Aliansi Masyarakat Adat Nusantara (AMAN), dan organisasi masyarakat adat nusantara telah melakukan kongres yang pertama pada tanggal 17 Maret 1999 di Hotel Indonesia, tahun 2003 kongres dilakukan di Tanjung Lombok Utara provinsi Nusa Tenggara Barat, pada Tahun 2007 Kongres dilaksanakan di Pontianak Kalimantan Barat, pada Tahun 2012 Kongres dilaksanakan di Tobelo Maluku Utara, termasuk juga dalam kongres Aliansi Masyarakat Adat Nusantara (AMAN) turut dihadiri oleh perwakilan masyarakat adat Kepaksian Pak Sekala Bekhak.

Dengan demikian, kesatuan masyarakatadat di wilayahwilayah Kabupaten Lampung Barat, diakui hak-hak adatnya baik yang menyangkut adat istiadat atau aturan-aturan yang berkaitan dengan adat itu Sendiri maupun yang berkaitan dengan tradisi adat atau etika dalam kehidupan sehari-hari, demikian juga halnya dalam pengelolaan hutan adat Pemerintah Republik Indonesia masih mengakui keberadaan hutan adat hal ini sebagaimana disebutkan didalam UUPA No. 5 Tahun 1960 
demikian juga terhadap pengelolaan potensi kelautan secara umum dilakukan secara tradisional yang dikenal dengan hak adat kelautan. Dibandingkan dengan hak ulayat atas tanah, maka tampak bahwa hak ulayat atas laut sebagai tradisi adat yang sudah berlangsung secara turun temurun dan dihormati oleh masyarakat adat setempat. Hal ini ternyata belum sepenuhnya diakui secara luas baik oleh pemerintah maupun pengusaha yang sebenarnya merupakan mitra penting dalam proses pembangunan.

Dalam konteks Undang-Undang yang mengatur tentang pengelolaan wilayah laut dan pesisir adalah Undang-Undang Nomor 27 Tahun 2007 tentang Pengelolaan wilayah pesisir dan pulau-pulau kecil. Di dalam undang-undang tersebut diatur hak pengusahaan Perairan Pesisir (HP-3), yang menurut pasal 18 dapat diberikan kepada :

a. Orang perorangan warga Negara Indonesia;

b. Badan hukum yang didirikan berdasarkan hukum Indonesia atau;

c. Masyarakat hukum adat

Adapun tentang jangka waktu pengelolaan, pasal 19 menyebutkan bahwa HP-3 diberikan untuk jangka waktu 20 (dua puluh) tahun dan dapat diperpanjang selama 20 (dua puluh) tahun untuk tahap pertama serta dapat diperpanjang lagi untuk tahap kedua sesuai dengan peraturan perundang-undangan yang berlaku.Terkait kedudukan masyarakat hukum adat maka Undang-Undang Nomor 27 Tahun 2007 pada pasal 21 ayat (4) 
huruf b secara tegas menyebutkan: "Mengakui, Menghormati, Dan Melindungi Hak-Hak Masyarakat Hukum Adat Dan/Atau Masyarakat Lokal" .9

Pasca putusan Mahkamah Konstitusi Republik Indonesia No. 35/PUU-X/2012 Tentang Uji Materil (Judicial Review) terhadap undang-undang No. 41 Tahun 1999 Tentang Kehutanan. Maka berdasarkan Permendagri No. 52 Tahun 2014 Tentang Pedoman Pengakuan dan Perlindungan Masyarakat Hukum Adat, dimana didalam Permendagri tersebut menyebutkan Gubernur dan Bupati/Walikota melakukan perlakuan dan perlindungan terhadap masyarakat hukum adat, mem bentuk panitia masyarakat hukum adat yang terdiri dari perwakilan intansi pemerintah terkait dan masyarakat hukum adat untuk melakukan identifikasi, verifikasi dan validitasi masyarakat hukum adat yang kemudian ditetapkan oleh Bupati atau Walikota berdasarkan rekomendasi dari panitia masyarakat hukum adat lebih lanjut dalam Permendagri tersebut menerangkan bahwa Gubernur dan Bupati/Walikota melakukan pengakuan dan perlindungan masyarakat hukum adat dimana perlakuan dan perlindungan masyarakat hukum adat tersebut melalui tahapan :
a. Tahapan identifikasi masyarakat hukum adat.
b. Tahapan Verifikasi dan Validasi masyarakat hukum adat.
c. Tahapan penetapan masyarakat hukum adat

\footnotetext{
${ }^{9}$ http://fhukum.unpatti.ac.id/artikel/hukum-pidana/364-perlindunganhukum-terhadap-hak-hak-masyarakat-hukum-adat-lampgdalam-pengelolaansumber-daya-alam-di-wilayah-pesisir-dan-laut
} 
Dalam melakukan identifiaksi masyarakat hukum adat Bupati/Walikota harus mencermati sejarah masyarakat hukum adat setempat, wilayah hukum adat, harta kekayaan atau benda benda adat, kelembagaan/system pemerintahaan adat.

Berkaitan dengan hal tersebut maka Pemerintah Kabupaten Lampung Barat menagcu pada ketentuan undangundang No. 6 Tahun 2015 tentang Pemerintahan Desa yang menyebutkan bahwa Pemerintah Daerah Provinsi, dan Pemerintah DaerahKabupaten Kota melakukan penataan kesatuan masyarakat hukum adat dan dijadikan menjadi Desa Adat. Kemudian satu kesatuan masyarakat hukum adat beserta hak tradisionalnya sesuai dengan prinsip Negara Kesatuan Republik Indonesia apabila kesatuan masyarakat hukum adat tersebut tidak mengganggu keberadaan Negara Kesatuan Republik Indonesia sebagai sebuah kesatuan politik dan kesatuan hukum yang tidak mengancam kedaulatan dan integritas Negara Kesatuan Republik Indonesia maka substansi norma hukum adatnya sesuai dan tidak bertentangan dengan ketentuan peraturan perundang-undangan.

Berkaitan dengan peran Pemerintah Daerah Kabupaten Lampung Barat dalam memberdayakan eksistensi peran masyarakat adat Kabupaten Lampung Barat, salah satunya adalah dengan mengeluarkan Perda Kabupaten Lampung Barat Nomor 18 Tahun 2004 Tentang Pengelolaan Sumber Daya Alam Dan Lingkungan Berbasis Masyarakat. Dengan dibuat dan ditetapkannya Perda ini, dapat diartikan bahwa PEMDA Lampung Barat secara langsung memberikan legitimasi sebagai 
bentuk pemberdayaan masyarakat adat diKabupaten Lampung Barat baik dalam hal pengelolaan hutan adat maupun dalam pelestarian tradisi-tradisi adat.

\section{Kesimpulan}

Berdasarkan pembahasan di atas, dapat diketahui Pemenuhan Hak Masyarakat Adat dalam penguasaan hutan adat di Kabupaten Lampung Barat telah diakomodir oleh Pemerintah Daerah Kabupaten Lampung Barat. Hal ini terbukti dengan terbentuknya Peraturan Daerah KabupatenLampung Barat Nomor 18 Tahun 2004 Tentang Pengelolaan Sumber Daya Alam dan Lingkungan Berbasis Masyarakat. Dengan adanya Peraturan Daerah Kabupaten Lampung Barat tersebut, telah memberikan perlindungan hak-hakkepada masyarakat adat yang ada di wilayah Kabupaten Lampung Barat sesuai dengan apa yang telah dimaksudkan oleh konstitusi Undang-Undang Dasar 1945 dan sesuai pula dengan apa yang dikehendaki melalui Putusan Mahkamah Konstitusi No. 35/PUU-X/2012. Artinya Pemerintah Daerah Kabupatan Lampung Barat telah memenuhi apa yang menjadi hak masyarakat adat di Kabupaten Lampung Barat atas tanah ulayatnya.

\section{Daftar Pustaka}

Beni Ahmad Saebani. 2009. Metode Penelitian Hukum. Pustaka Setia : Bandung. 
Hendra Nurtjahjo dan Fokky Fuad. 2010.Legal Standing Kesatuan

Masyarakat Hukum Adat Dalam Berperkara di Mahkamah

Konstitusi.Salemba Humanika : Jakarta.

HusenAlting. 2010.Dinamika Hukum dalam Pengakuan dan

Perlindungan Hak Masyarakat Hukum Adat Atas Tanah.

LaksBangPRESSindo : Yogyakarta.

Hilman Hadikusuma. 2003.Pengantar Ilmu Hukum Adat Indonesia.CV Mandar Maju : Bandung.

IndriyantoEkologi Hutan. 2010. Bumi Aksara : Jakarta.

Lexy J. Moleong.2011. Metode Penelitian Kualitatif. Rosda : Bandung.

LimeiPasaribu.

2011.KeberadaanHakUlayatdalamMasyarakatHukumAdatB atakToba

diKecamatanNassauKabupatenTobaSamosir.Tesis.IlmuHuk um.ProgramStudiMagister KenotariatanUSU.

Rikardo Simarmata. 2006.Pengakuan Hukum Terhadap Masyarakat Adat di Indonesia.UNDP Regional Centre in Bangkok : Jakarta.

Suharsimi Ari Kunto. 1998.Prosedur Penelitian suatu Pendekatan

Praktek. Edisi Revisi IV. Rineka Cipta : Jakarta.

Sulistyowati Irianto dan Shidarta (Editor). 2009.Metode Penelitian

Hukum.Konstelasi dan Refleksi. Penerbit Yayasan Obor Indonesia : Jakarta.

Urip Santoso. 2010. Hukum Agraria Dan Hak-Hak Atas Tanah. Kencana : Jakarta.

Wisnu Arya Wardhana. 2004.Dampak Pencemaran Lingkungan.Andi Offset: Yogyakarta. 
Mahkamah Konstitusi Republik Indonesia.Dua Tahun Usiamu. $\begin{array}{llll}\text { Putusan } & \text { MK-35 } & \text { Masih }\end{array}$ MacanOmpong.http://www.mahkamahkonstitusi.go.id/in dex.php?page=web.Berita\&id=10879\#.V0SQwxLy3IV. senin.18 Mei 2015 17.01 WIB

Berton Nababa. Paper berjudul Pengakuan Konstitusional Keberadaan Wilayah Hutan Masyarakat Adat Yang Masih Terabaikan Hampir 2 Tahun Perjalanan Putusan MK No.35/PUU-X/2012

BPS. Luas Kawasan Hutan dan Perairan Menurut Provinsi (ribu ha). https://www.bps.go.id /linkTabelStatis/view/id/1716. diakses pada 16-05-2016 pukul 14.15 wib.

Undang-Undang Dasar Negara Republik Indonesia Tahun 1945

Putusan Mahkamah Konstitusi Nomor : 35/PUU-X/ 2012

Uu No. 39 Tahun 1999 tentang HAM

Undang-Undang Nomor 41 Tahun 1999 tentang Kehutanan

UU No. 6 Tahun 2015 Tentang Desa.

Peraturan Menteri Dalam Negeri Republik Indonesia Peraturan Menteri Dalam Negeri Nomor 52 Tahun 2014 Tentang Pedoman Pengakuan Dan Perlindungan Masyarakat Hukum Adat. Permendagri ini merupakan payungkan hukum yang diperuntukkan sebagai pedoman dan pengakuan Masyarakat Hukum Adat pasca putusan MK.

Peraturan Menteri Kehutanan Republik Indonesia Nomor : P.62/MENHUT-II/ 2013 Tentang Perubahan Atas peraturan Menteri Kehutanan Nomor P.44/MENHUT-II/2012 Tentang Pengukuhan Kawasan Hutan. Pasal 24A. Pengukuan masyarakat hukum adat masih terkendala karena untuk 
ISTINBATH : JURAGL HUKUM. VOl. I 5 nO.2. nOV. 2018

menerbitkan Perda diperlukan biaya dan prosedur hukum yang cukup panjang

Surat Edaran Menteri kehutanan nomor : SE. 1/Menhut-II/2013 tentang Putusan MK No. 35/PUU-X/2012 tanggal 06 mei 2013

Peraturan Menteri Agraria Dan Tata Ruang/Kepala Badan Pertanahan Nasional Nomor 9 Tahun 2015 Tentang Cara Penetapan Hak Komunal Atas Tanah Masyarakat Hukum Adat Dan Masyarakat Yang Berada Dalam Kawasan Tertentu. 